\title{
A Note on Measuring the Unofficial Economy in the Former Soviet Republics
}

\author{
By: Michael Alexeev and William Pyle
}

William Davidson Working Paper Number 436

September 2001 


\title{
A Note on Measuring the Unofficial Economy in the Former Soviet Republics
}

\author{
Michael Alexeev*
}

and

William Pyle*

September 2001

* D epartment of Economics, Indiana University, Bloomington, IN 47405, phone: (812) 855-7103, fax: (812) 8553736, e-mail: malexeev@ indiana.edu

${ }^{* *}$ Economics D epartment, Middlebury College, Middlebury, VT 05753, phone: (802) 443-3240, fax: (802) 443-2084, e-mail: wpyle@middlebury.edu 


\section{Abstract}

This note argues that the most commonly used estimates of the size of the unofficial economies in the former Soviet republics are flawed. Most important, they are based on calculations that disregard the variation in unofficial economic activity across space in the pre-transition Soviet Union. In addition, these estimates appear to understate the size of the unofficial economies in these countries. We propose alternative estimates and find that they are more strongly related to the institutional factors commonly used to explain the size of the unofficial sector. Our estimates also show that the size of a country's pre-transition unofficial economy is an important predictor of its size during the transition. This suggests that the size of the unofficial economy is to a large extent a historical phenomenon only partly determined by contemporary institutional factors.

JEL classification: $017, \mathrm{P} 2, \mathrm{P} 3$

Keywords: hidden economy, transition economies 


\section{William Davidson Institute Working Paper 436}

\section{Non-Technical Summary}

Conventional wisdom holds that the unofficial economies in post-socialist countries are quite large. With state institutions still developing the capacity to regulate and measure market-based activities, it is widely believed that a significant share of the goods and services produced in these economies does not enter into official estimates of GDP. But how much? Arriving at a precise answer to this question is impossible, and even a reasonable approximation is not easy to come by. Nor is the answer trivial in its consequences. A better sense of the size (and nature) of the unofficial economy may lead to a re-assessment of output dynamics during the transition and influence policies from public finance to social protection.

In this note, we argue that the most frequently cited size estimates of the unofficial economies in the FSU are flawed by an assumption that the unofficial economies of the former Soviet republics accounted for the same 12\% share of their total GDP in 1989. Starting from that assumption Kaufmann and Kaliberda (1996) and Johnson, Kaufmann and Shleifer (1997) assumed a near unit-elasticity relationship between measured electricity consumption and total economic activity -- measured and unmeasured. This approach led them to conclude that by the middle of the 1990s, unofficial economies in the FSU ranged from a low of $6.5 \%$ in Uzbekistan to a high of $62.6 \%$ in Georgia.

We use both labor input and household income data collected in the Berkeley-Duke survey project to show that the average size of the unofficial economies in the Soviet republics, most likely, exceeded $12 \%$ of total GDP and, certainly, varied a great deal in size across space. We re-estimate the sizes of republic-level unofficial economies at the end of the socialist period and confirm the significant variation in the extent of unmeasured economic activity. Specifically, the Berkeley-Duke data suggest relatively high amounts of unofficial activity in the Caucasian and Central Asian republics and relatively low levels in the European republics. Using these new estimates, we apply the same "electricity consumption" methodology used in the aforementioned studies to trace the dynamics of the unofficial economy during the transition. This leads us to a revised set of estimates for the size of unofficial economies in 1995. Our estimates range from a low of $21.9 \%$ in Estonia to a high of $71.4 \%$ in G eorgia.

In a series of regressions, we demonstrate that our set of revisions is more closely related to governance indices that had previously been shown to be associated with unofficial economic activity. Because of the potential simultaneity between governance and the unofficial economy, we also present the results using two variables to instrument for the governance regressors. The comparative results remain similar to those in the OLS regressions.

We also show that the previous estimates may have biased the conclusions of the researchers who used them. Surprisingly, Johnson $\&$ al. (1997) found that the size of a country's unofficial economy in 1989 did not have a statistically significant impact on the size of its unofficial economy in 1995. In regressions with our estimates, however, the pretransition status of the unofficial economy plays a prominent role, partly at the expense of the governance indicators. This outcome suggests that the size of the unofficial economy is to a large extent a historical phenomenon only partly determined by contemporary governance indicators, which themselves may be historically determined and not easily modified by policy initiatives. 


\section{William Davidson Institute Working Paper 436}

\section{A Note on Measuring the Unofficial Economy in the Former Soviet Republics}

\section{Introduction}

Conventional wisdom holds that the unofficial economies in post-socialist countries are quite large. With state institutions still developing the capacity to regulate and measure market-based activities, it is widely believed that a significant share of the goods and services produced in these economies does not enter into official estimates of GDP. But how much? Arriving at a precise answer to this question is impossible, and even a reasonable approximation is not easy to come by. Nor is the answer trivial in its consequences. A better sense of the size (and nature) of the unofficial economy may lead to a re-assessment of output dynamics during the transition and influence policies from public finance to social protection.

Kaufmann and Kaliberda (1996) were the first to apply a consistent methodology to measuring the unofficial economies in formerly socialist countries. Drawing on the same approach, Johnson et al. (1997) updated Kaufmann and Kaliberda's work, producing estimates for the size of the unofficial economy in eleven former Soviet republics and six Central and East European countries in 1995. Subsequent studies by Johnson et al. (1998), Friedman et al. (2000), Schneider and Enste (2000), Rosser et al. (2000) and Johnson and Kaufmann (2001) used these estimates to evaluate the causes and consequences of cross-country variation in unofficial economic activity. Although this work has done much to advance understanding of unofficial economies during the transition, we feel that the size estimates of Kaufmann and Kaliberda (1996) and Johnson et al. (1997) were significantly flawed by an assumption that the unofficial economies of the pre-transition former Soviet republics accounted for the same 12\% share of their total GDP.

Below we address this important element of the discussion of the post-socialist unofficial economy. Using data from the Berkeley-Duke survey project, we show both that the average size of the unofficial economies in the Soviet republics was significantly larger than assumed by Kaufmann and Kaliberda (1996) and that there was a good deal of variation in their size across space. ${ }^{1}$ On the basis of the Berkeley-Duke data, we re-estimate the size of the unofficial economies at the end of the socialist period. Using these new estimates, we apply the same methodology used by both Kaufmann and Kaliberda (1996) and Johnson et al. (1997) to trace the dynamics of the unofficial 


\section{William Davidson Institute Working Paper 436}

economy during the transition. This leads us to a revised set of estimates for the size of unofficial economies in 1995. We conclude with a series of side-by-side comparisons. These demonstrate that our revisions are more closely related than the previous estimates to a set of governance variables that have been shown to be associated with unofficial economic activity. Perhaps even more important, we show that the flawed estimates may have biased the conclusions of the researchers who used them. Johnson et al. (1997) found, surprisingly, that pre-transition conditions had no impact on the size of unofficial economies in 1995. Specifically, they point out that the size of a country's unofficial economy in 1989 did not have a statistically significant impact on the size of its unofficial economy in 1995. In regressions with our estimates, however, the pre-transition conditions play a prominent role, partly at the expense of the governance indicators. This outcome suggests that the size of the unofficial economy is to a large extent a historical phenomenon only partly determined by contemporary governance indicators, which themselves may be historically determined and not easily modified by policy initiatives.

\section{The Electricity Consumption Methodology}

The initial study by Kaufmann and Kaliberda started from the observation that in the short run electricity consumption and total economic activity move in parallel fashion, with near unitelasticity. ${ }^{2}$ Thus the difference between the growth rates of measured GDP and electricity consumption can yield an estimate of the change in the size of the unofficial economy, which Kaufmann and Kaliberda define as "the unrecorded value added by any deliberate misreporting or evasion by a firm or individual (p. 83).”

Kaufmann and Kaliberda sub-divided the post-socialist countries into three groups on the basis of differences in the timing and scope of policy reform. ${ }^{3}$ Since energy prices were liberated earlier and more extensively in Central and Eastern Europe, that region's countries were assumed to be more efficient consumers of energy than others in the post-socialist world. Electricity consumption, that is, was presumed to rise more slowly and fall more quickly relative to rises and falls, respectively, in total output. Energy prices were liberalized later in the Baltic economies and still later and not as comprehensively in the rest of the former Soviet Union. Following this tripartite division, Kaufmann and Kaliberda applied the output elasticity of electricity-consumption measures that are re-produced in Table 1. 


\section{William Davidson Institute Working Paper 436}

By themselves, these elasticities are useful only for estimating the change in the size of the unofficial economy for given dynamics in measured output and electricity consumption. In order to use them for computing the contribution of a country's unofficial economy to its total GDP, one needs to work from an estimated baseline. For instance, if the initial share of the unofficial economy in a country's total GDP is estimated to be $10 \%$, and if official (i.e., measured) GDP and electricity consumption grow by $3 \%$ and 5\%, respectively, the unofficial economy would be presumed to have grown to $11.7 \%$ of all economic activity. ${ }^{4}$ Thus, to estimate the size of the unofficial economy in the former Soviet republics during the transition, Kaufmann and Kaliberda worked from estimates of their sizes in the pre-transition period.

Since there were no widely recognized estimates of the sizes of the unofficial economies in the Soviet republics, Kaufmann and Kaliberda assumed that the size of the unofficial economy was uniform across the USSR. Without being specific, they wrote:

On the basis of the Berkeley-Duke research project on the USSR Second Economy $\ldots$ as well as the work of $\mathrm{J}$. Braithwaite, estimates ranging roughly between 10 and 15 percent of total economic activity were arrived at. Thus ... we use the 1989 midpoint estimate share of unofficial activities of 12 percent (pp. 9394).

They relied upon other country-level studies to establish the size of unofficial economies in 1989 in Central and Eastern Europe. ${ }^{5}$ All the estimates appear in the first column of Table 2.

By comparing the dynamics of measured output and electricity consumption and applying the noted estimates of elasticities, Kaufmann and Kaliberda arrived at size estimates for 1994. Using a year's worth of additional data, Johnson et al. (1997) followed the same approach and produced estimates for $1995 .{ }^{6}$ As shown in Table 2, they found that the unofficial economy represented a significant share of total output both prior to and during the transition. But whereas in Central and Eastern Europe there was generally little change in its size relative to measured output, there was a significant increase in its relative magnitude in the former Soviet republics. This trend appears to have been most pronounced in the Caucasian states of Azerbaijan and Georgia where unofficial activity is reported to have jumped from twelve percent to well over half of total GDP.

The estimates of Kaufmann and Kaliberda (1996) and Johnson et al. (1997) have been recognized as the most comprehensive, internally consistent set of estimates of the unofficial economy in post-socialist countries. But their approach has been criticized. In general terms, it has 


\section{William Davidson Institute Working Paper 436}

been noted that unofficial economy activities can vary greatly with respect to the amount of electricity that they require; likewise, the differences in elasticities across space and time can be considerable and quite difficult to calibrate (Shneider and Entse, 2000). Lacko (2000), although an advocate of using electricity consumption, voices skepticism at some of the estimates produced by Kaufmann and Kaliberda's methodology. In particular, she suggests that their findings of significant cross-country variation in unofficial economy dynamics do not pass the believabilty test. She proposes an alternative methodology that involves econometrically estimating per capita household electricity consumption. Her methodology is considerably more complicated than Kaufmann and Kaliberda's and it has its own serious shortcomings, some of which are noted by Schneider and Enste (2000). Moreover, her estimates also fail the belivability test. For example, according to Lacko, the shares of the hidden economy in Latvia and Lithuania far exceed those in Russia, Uzbekistan, and Kazakhstan. This is hard to reconcile with anecdotal evidence and common perception. Given these considerations and the fact that Kaufmann and Kaliberda's estimates have been more commonly cited, we concentrate on their approach. We will, however, compare our estimates with those by Lacko as well.

We agree with Kaufman and Kaliberda that changes in electricity consumption can serve as a consistent, albeit very rough, metric for assessing unofficial economy dynamics across countries. We note, however, the crucial role of the initial estimates in evaluating the size of the unofficial economy in any given year via electricity consumption. Surprisingly, Kaufmann and Kaliberda did not devote much space to justifying their assumption that the size of the unofficial economy in 1989 was uniform across all Soviet republics. Nor do they offer much support for their estimate that the unofficial economy accounted for only $12 \%$ of total Soviet GDP. In the next section, we will use the publications of the same Berkeley-Duke project that was referenced by Kaufmann and Kaliberda to arrive at dramatically different estimates of the Soviet unofficial economy circa 1989.

\section{The Berkeley-Duke Project and the Estimates of the Unofficial Economy Size}

Soviet and Western researchers proffered a number of estimates of the size of the unofficial economy in the Soviet Union. ${ }^{7}$ Usually, these estimates were not presented as a share of GDP because it is often unclear to what extent unofficial economic activities add to the official GDP. For example, if a home owner rents out part of his home in a transaction that is not declared to the tax authorities, this is presumably part of the unofficial economy. But the official GDP includes not only the value of paid rent, but also the imputed rent on owner-occupied housing. Therefore, the 


\section{William Davidson Institute Working Paper 436}

unofficial rental income would be included in the GDP although it might be misclassified as imputed rent instead of paid rent. Also, GDP calculations are often based on sources such as consumer surveys that may take into account many unofficial transactions. ${ }^{8}$ We will disregard these methodological issues and follow Kaufmann and Kaliberda in assuming that the share of the unofficial economy in GDP is roughly equal to some measure of the share of unofficial economic activity in all economic activity. For example, one such measure may be the share of labor inputs used in the unofficial economy.

As we mentioned in the previous section, Kaufmann and Kaliberda did not fully develop the justification for their 1989 estimates. They simply made a rather general reference to various issues of Berkeley-Duke Occasional Papers on the Second Economy in the USSR (BDOP) and a report by Braithwaite (1995).9 We have been able to find only two more or less general estimates of the size of the Soviet unofficial economy based on the Berkeley-Duke survey data in the BDOP. First, Grossman (1991) presents measures of the share of urban household income derived from the second economy. Second, Treml (1992) estimates the amount of labor inputs used in the Soviet second economy in urban areas. Next, we will briefly examine these estimates and argue that Kaufmann and Kaliberda's $12 \%$ estimate most likely understates the size of the unofficial economy in the Soviet Union as a whole and most certainly fails to capture the variation in its size across the individual republics.

A note on terminology is in order. Both Grossman and Treml defined the second economy in the Soviet Union as all economic activity that either is directly for private gain or knowingly contravenes the law, or both. Kaufman and Kaliberda define the unofficial economy as constituting activity that is not recorded in the official GDP. Clearly, Grossman's definition is broader because it includes private legal economic activities that were included in the country's official statistics. But for urban USSR circa 1979, the year to which both Grossman's and Treml's second economy estimates refer, this distinction is likely to be unimportant since the official private sector was negligible.

According to Treml's estimates, $11.8 \%$ of all working time in the Soviet urban economy in 1979 was spent on private economic activities. Assuming that the productivity in the unofficial economy was the same as in the official economy, this number suggests that $12 \%$ of GDP would be a reasonable estimate for the size of the unofficial economy in 1979. Is the assumption of equal labor productivity in the two economies reasonable? There are arguments both for and against. For example, the unofficial economy's productivity may be higher, because it offered much more 


\section{William Davidson Institute Working Paper 436}

powerful incentives. On the other hand, the capital-labor ratio in the unofficial economy was probably lower than in the official one, suggesting that the productivity in the former was also lower, other things being equal. ${ }^{10}$ Ideally, we would like to have estimates for the value of output rather than inputs in both economies.

Based on the same Berkeley-Duke survey data, Grossman (1991) estimates that Soviet urban households derived on average over 30\% of their total income from unofficial or second economy sources. In evaluating these estimates, one should keep in mind that household income from unofficial sources probably included at least part of the capital income from the second economy, while official capital income, to the extent it was not distributed in transfers and wage subsidies, accrued to the state. Nonetheless, the 30\% figure suggests that productivity was probably higher in the unofficial economy than in its official counterpart.

Whether or not one accepts either the $12 \%$ or the $30 \%$ figure as a suitable estimate of the share of the unofficial economy in total GDP, it is almost certain that this share increased between 1979, the modal reference year for the Berkeley-Duke survey, and 1989. The reasons for this growth, particularly in the second half of the 1980's, included increased imbalances between household incomes and opportunities to spend it in the official economy, new opportunities for unofficial economic activities engendered by greater autonomy of state enterprises, and Gorbachev's antialcohol campaign that resulted in an explosion of bootlegging and exacerbated inflationary pressures. ${ }^{11}$ Later, we will extrapolate the estimates based on Berkeley-Duke data from 1979 to 1989 and show that Kaufmann and Kaliberda significantly underestimated the size of the Soviet unofficial economy prior to the transition. More important, the Berkeley-Duke study makes clear that Kaufmann and Kaliberda erred by not making any allowance for the substantial differences in the volume of unofficial economic activity across the former Soviet republics. Grossman (1991), in breaking down urban household income data from official and unofficial sources for several groups of former Soviet republics, presents the most comprehensive data that can be used to make quantitative estimates in this regard. Table 3 summarizes the relevant numbers.

Grossman does not present incomes for some of the republics. Therefore, for those republics we had to make estimates using aggregated regional data. For example, to calculate incomes for the Baltic republics, we took out the data on Russia from the Russia-Baltic subzone, using the following formula:

$$
\mathrm{I}_{\mathrm{B}}=\left(\mathrm{I}_{\mathrm{RB}} \cdot \mathrm{N}_{\mathrm{RB}}-\mathrm{I}_{\mathrm{R}} \cdot \mathrm{N}_{\mathrm{R}}\right) /\left(\mathrm{N}_{\mathrm{RB}}-\mathrm{N}_{\mathrm{R}}\right)
$$




\section{William Davidson Institute Working Paper 436}

where I stands for per capita income, $\mathrm{N}$ denotes the number of observations, and subscripts $\mathrm{B}, \mathrm{RB}$, and $\mathrm{R}$ refer to the Baltic republics, the Russia-Baltic subzone, and Russia, respectively. We then assumed that the size of the unofficial economy was the same across republics within each region for which we could not obtain separate estimates. For example, Belorussia and Moldavia were presumed to have the same shares. And we assumed the same for the republics in the South zone as well as for those in the Baltic region. The results of these calculations are shown in Table 4 below. Notice that the shares of unofficial incomes vary in the range from 0.27 in Russia to 0.50 in the South zone.

As we suggested earlier, the fractions in the last column of Table 4 probably overestate the share of the unofficial economy in Soviet GDP because they do not account for capital income accrued to the Soviet state. Thus, on the basis of Treml's (1992) esimtates of labor inputs, we adopt the $12 \%$ figure as a conservative estimate of the share of unofficial economic activity in total GDP. However, unlike Kaufmann and Kaliberda, we take this share to refer to 1979 since that was the year for which Treml made his estimate.

In order to determine the share of the unofficial economy in the Soviet Union in 1989, we use the same technique that Kaufmann and Kaliberda used to project their estimates from 1989 to 1995. According to the CIA estimates, between 1980 and 1989, Soviet official GDP grew by approximately $21 \%$. Over the same period, electric power output increased by about $36 \%{ }^{12}$ Assuming that in 1979 the unofficial economy contributed 12\% of total GDP and using unitary elasticity of total GDP with respect to electricity output, we can infer that by 1989 the unofficial economy share grew to about $22 \%{ }^{13}$ This is the base estimate that we will use in our further calculations.

Next, we determine the unofficial economy shares in eleven Soviet republics. (Following Kaufmann and Kaliberda, we exclude four republics from our calculations because we do not have adequate electricity consumption data to estimate unofficial economy shares in 1995.) While Grossman's estimates of second economy household incomes in different republics may not measure the share of the unofficial economy in the GDP, we assume that his estimates adequately reflect the size of unofficial economies in these republics in relative terms. We assume, for example, that because South zone households obtained 50\% of their incomes from the second economy versus only $27 \%$ in Russia, the share of the unofficial economy in GDP was almost twice as high in the republics of the South zone as it was in Russia. Given the relative shares shown in Table 4 and 


\section{William Davidson Institute Working Paper 436}

using republican GNP data we can calculate the size of the unofficial economy in each republic, making sure that the share of the unofficial economy for these republics as a group equals $22 \%$. Table 5 presents the results. In order to obtain the $22 \%$ share, we had to scale the shares implied by Grossman by approximately two-thirds. For example, for Azerbaijan, 0.5·0.66=0.33.

Finally, we project our 1989 unofficial economy estimates to 1995, again using Kaufmann and Kaliberda's technique. Using our estimates for the unofficial economy in 1989 and the GDP and electricity output indices from Johnson et al. (1997), we calculate the 1995 shares according to the following formula: ${ }^{14}$

$$
\mathrm{UE}_{95}=1-\left(1-\mathrm{UE}_{89}\right) \cdot \mathrm{X}_{\mathrm{OF}} / \mathrm{X}_{\mathrm{EL}}
$$

where UE denotes the share of the unofficial economy in total GDP and $\mathrm{X}_{\mathrm{OF}}$ and $\mathrm{X}_{\mathrm{EL}}$ denote, respectively, the indices of official GDP and total output as proxied for by electricity consumption. The results of these calculations are presented in the next to last column of Table 6. For comparison, we also show the estimates that Johnson et al. (1997) obtained using Kaufmann and Kaliberda's methodology. In the next section, we will compare both their and our estimates for 1995 in a series of side-by-side regressions.

\section{Side-by-Side Comparisons}

One might expect that the more intrusive and the less helpful government is vis-a-vis business, the more likely firms are to exit into the unofficial economy. More burdensome taxation and regulation, more corruption and poorer provision of public goods all are likely to encourage evasion from government's reach. But evaluating this proposition econometrically presents problems. First, variables that measure state policies and capabilities tend to be highly correlated and so multicollinearity becomes a problem when more than one are used as regressors. Second, governance may be endogenous to the size of the unofficial economy. For example, when firms enter the unofficial economy, they pay less tax and thereby diminish government's ability to provide public goods. This simultaneity bias can only be alleviated if appropriate instrumental variables can be found.

In addition to governance, it would also be reasonable to expect that a country's traditions and norms would play an important role in determining the extent of unofficial economic activity. Such virtually unmeasurable factors may at least be partly reflected in the historical size of the 


\section{William Davidson Institute Working Paper 436}

unofficial economy in a country. For this reason, in what follows, we highlight regressions in which the pre-transition share of the unofficial economy serves as one of the controls.

Several recent studies have uncovered a strong empirical relationship between the size of unofficial economies and governance. Johnson et al. (1997) found unofficial economy size in transitioning countries to be inversely related to fairer taxation, fewer regulations and more effective provision of public goods. Johnson et al. (1998) and Friedman et al. (2000) further confirmed strong associations between unofficial activity and measures of governance using expanded databases that included OECD and developing countries.

Applying the same approach, we compare the performance of our estimates of second economy size with those of Johnson et al. (1997). While our point estimates of the relevant coefficients are broadly similar to theirs, we find two important differences that support our estimates. First, our regressions exhibit better fit as measured by both the $\mathrm{R}^{2}$ values and the statistical significance of the coefficients, which, of course, are equivalent for the bivariate regressions. Second, the coefficient on the pre-transition size of unofficial economy is highly significant in several of our regressions, while it is statistically insignificant in all of the corresponding Johnson et al. (1997) regressions. We discuss both differences in some detail in turn.

The value of $\mathrm{R}^{2}$ can serve as a test of the accuracy of the dependent variable only under rather limited circumstances. For example, let the true relationship between a dependent variable Y and independent variable $\mathrm{X}$ be $\mathrm{Y}=\alpha+\beta \mathrm{X}+\varepsilon$, where $\alpha$ and $\beta$ are constant coefficients and $\varepsilon$ is a random error that satisfies the OLS assumptions. Suppose now that we have two measures of Y that have errors denoted, respectively, by J and K. In other words, under the first measure we observe values $\mathrm{Y}+\mathrm{J}$, while under the second we observe $\mathrm{Y}+\mathrm{K}$. Suppose also that when we regress $\mathrm{Y}+\mathrm{J}$ and $\mathrm{Y}+\mathrm{K}$ on $\mathrm{X}$, we obtain the respective $\mathrm{R}^{2}$ values of of $\mathrm{r}_{\mathrm{J}}$ and $\mathrm{r}_{\mathrm{K}}$. It is straightforward to show that if the values of $J$ and $K$ are uncorrelated with either $Y$ or $\varepsilon$, then $r_{K}>r_{j}$ implies that the variance of $K$ is lower than the variance of $\mathrm{J}$. This would indeed suggest that $\mathrm{Y}+\mathrm{K}$ is a better estimate of $\mathrm{Y}$ than $\mathrm{Y}+\mathrm{J}$ if both $\mathrm{K}$ and $\mathrm{J}$ have the same mean. However, if $\mathrm{K}$ and $\mathrm{J}$ have different means, the value of $\mathrm{R}^{2}$ says nothing about which error has a smaller mean. This is because the difference in the means of the measurement errors of the dependent variables would be reflected only in the point estimates of the constant term. Therefore, if the above assumptions on the measurement errors are satisfied, the better fit of our regressions favors our estimates of the unofficial economies across the former 


\section{William Davidson Institute Working Paper 436}

Soviet republics. As for the higher average size of unofficial economy according to our estimates, we can rely only on the arguments presented in the previous section.

With the above discussion in mind, consider Table 7. It reports the outcomes from three pairs of bivariate regressions, each of which uses the same governance variables as regressors as Johnson et al. (1997). ${ }^{15}$ The third column in Table 7 reproduces results presented in Johnson et al. (1997) for fifteen transitioning countries -- the six East European countries and nine of the former Soviet republics listed in the bottom half of Table 2. The results recorded in column four are similarly derived with the exception that they are based on our estimates for the relative size of the unofficial economy. ${ }^{16}$

Although they produce estimates for the unofficial economies of Belarus and Uzbekistan, Johnson et al. (1997) do not include these two in their regressions. They argue that the governments in these two countries were so repressive that "entrepreneurs [could not] switch into the unofficial sector." This strikes us as an odd line of reasoning. Generally, all governments try to prevent entry into the unofficial sector. And, no doubt, there is a good deal of variation in their capabilities. But these are the very sort of differences in governance that our regressors are designed to capture. We, therefore, run the same set of regressions with Belarus and Uzbekistan. ${ }^{17}$ Using the expanded set of seventeen countries, the results for Johnson et al.'s (1997) and our estimates are presented side-byside in the first two columns of Table 7. Columns five and six show the results of the same regressions run on just the eleven former Soviet republics for which we developed new estimates.

All the variables in these regressions have the expected negative signs. Better governance, that is, is associated with smaller unofficial economies. But the series using our re-estimates offer stronger support for this proposition. Comparing the $\mathrm{R}^{2}$ values across each pair of regressions using the same governance variable and the same sample of countries, the ones using our re-estimates are almost uniformly higher. With the exception of "regulation" (for which we do not have a complete set of data for all seventeen countries), governance variables explain more of the variation in the size of the second economy as we have estimated it. Furthermore, plugging our re-estimates into the larger seventeen country data set, we find that all five of the variables are significant at the $1 \%$ level; only one, however, is significant at this level using the Johnson et al. (1997) estimates.

Because of the potential simultaneity between governance and the unofficial economy, Table 7 also presents the results using two variables to instrument for the governance regressor: the distance of the country's capital city from Brussels and a dummy variable that indicates whether the 


\section{William Davidson Institute Working Paper 436}

country used to be part of the Soviet Union. The comparative results are similar to those in the OLS regressions.

A somewhat surprising feature of Johnson et al.'s (1997) regressions is the lack of any strong relationship between the pre- and post-transition shares of the unofficial economy. As shown in Table 8, in their regressions, none of the coefficients on their 1989 share estimates are statistically significant in determining 1995 shares. This is particularly unexpected because in the absence of any cross-country variation in the rate of structural change during the 1989-1995 period, the correlation between the two sets of shares would have been perfect. Did the transition produce such a radical change of regime with respect to the unofficial economy share of GDP that the post-transition governance indicators became the only significant explanatory factor? In contrast to Johnson et al. (1997), our estimates show that this was not the case. The pre-transition shares of the unofficial economy are positive and highly significant in all our OLS regressions for 15 economies and are significant at least at the $10 \%$ level in our 17-economy regressions (see Table 8). While this correlation is natural because we work with levels (shares) rather than growth rates, we would argue that the correlation is enhanced because the pre-transition shares of unofficial economy could be viewed as proxies for cultural environment and historical factors in each country. ${ }^{18}$ To the extent that this is the case, the positive relationship between the 1989 and 1995 shares suggests that the shares of the unofficial economy are path-dependent and only partly determined by the posttransition governance environment. Finally, given that the positive relationship between the 1989 and 1995 shares is to be expected, the fact that it exists for our estimates reinforces their validity relative to the estimates produced by Kaufmann and Kaliberda.

We present additional results in the Appendix tables. All offer further confirmation of the conclusions drawn from Table 7. Table 1A re-produces regressions that control for being a former Soviet republic. Table $2 \mathrm{~A}$ presents the same set of bivariate regressions run in Table 7 but makes the comparison between our and Lacko's estimates. Table 3A runs the same regression as in Table 7 but for a newer set of governance variables recently released by the World Bank. The $\mathrm{R}^{2}$ values for our estimates and the significance of the coefficients are consistently higher in the pairwise comparisons.

\section{Conclusion}

In this paper, we argue that the most commonly used estimates of the shares of the unofficial economy in the former Soviet republics are flawed in two important respects. First, the 


\section{William Davidson Institute Working Paper 436}

estimates of Kaufmann and Kaliberda and Johnson et al. (1997) disregard the variation in the development of unofficial economies across space in the former Soviet Union. Second, their estimates for 1989 and, as a consequence, for 1995 significantly understate the average size of unofficial economies in this entire group of countries. We propose our own estimates and compare the two sets by evaluating how strongly they are related to the institutional factors commonly used to explain the size of the unofficial sector. We find that our estimates, combined with Kaufmann and Kaliberda's estimates for a few other transition economies, are more strongly associated with the explanatory variables as measured by the $\mathrm{R}^{2}$ values and the statistical significance of the coefficients in almost all regressions.

In addition, we question the validity of Kaufmann and Kaliberda's estimates in view of the fact that their 1995 unofficial economy shares are uncorrelated with their 1989 estimates. The absence of a positive correlation is surprising because the levels of unofficial activity are unlikely to change radically and differently across countries over six years, even during the economic transition. In contrast, our 1995 estimates are clearly positively correlated with our 1989 estimates. Moreover, the 1989 shares remain a significant explanatory factor in our regressions even in the presence of explanatory governance variables, suggesting perhaps that the pre-transition starting point is important above and beyond the institutional environment that was achieved in the process of transition.

Finally, we compare the goodness of fit of our estimates with those generated by Lacko (2000). Here again, our estimates perform better than hers in the regressions. 


\section{William Davidson Institute Working Paper 436}

\section{References}

Alexeev, M. (1997), 'The Russian Underground Economy in Transition,' in Lippert, O. and M. Walker (eds.), The Underground Economy: Global Evidence of Its Size and Impact, Vancouver, Canada: The Fraser Institute, pp. 255-273.

Alexeev, M. and V. Treml (1994), 'The Growth of the Second Economy in the Soviet Union and Its Impact on the System,' in Campbell, R. (ed.), The Postcommunist Economic Transformation, Boulder: Westview Press, pp. 221- 247.

Braithwaite, J. (1995), 'From Second Economy to Informal Sector: The Russian Labor Market in 'Transition,' ESP Discussion Paper Series, No. 58, World Bank.

Dobozi, I. and G. Pohl (1995), 'Real Output Decline in Transition Economies -- Forget GDP, Try Power Consumption Data!' Transition Newsletter, 6:1-2, pp. 17-18.

Friedman, E., S. Johnson, D. Kaufmann and P. Zoido-Lobaton (2000) 'Dodging the Grabbing Hand: The Determinants of Unofficial Activity in 69 Countries,' Journal of Public Economics, 76, pp. 459-493.

Grossman, G. (1991), 'Wealth Estimates Based on the Berkeley-Duke Émigré Questionnaire: A Statistical Compilation, ' Berkeley-Duke Occasional Papers on the Second Economy in the USSR, No. 27, May.

Johnson, S. and D. Kaufmann (2001), 'Institutions and the Underground Economy,' in Havrylyshyn, O. and S. Nsouli (eds.), A Decade of Transition: Achievements and Challenges, Washington, D.C.: International Monetary Fund.

Johnson, S. D. Kaufmann and A. Shleifer (1997), 'The Unofficial Economy in 'Transition,' Brookings Papers on Economic Activity, 2, pp. 159-221.

Johnson, S. D. Kaufmann and P. Zoido-Lobaton (1998), 'Regulatory Discretion and the Unofficial Economy,' American Economic Review, 88:2, pp. 387-392.

Kaufmann, D. and A. Kaliberda. (1996), 'Integrating the Unofficial Economy into the Dynamics of Post-Socialist Economies: A Framework for Analysis and Evidence' in Kaminski, B. (ed.) Economic Transition in Russia and the New States of Eurasia, London: M.E. Sharpe, pp. 81-120.

Lacko, M. (2000), 'Hidden Economy -- An Unknown Quantity: Comparative Analysis of Hidden Economies in Transition Countries, 1989-95,' Economics of Transition, 8:1, pp. 117-149.

Levine, H. (1983), 'Possible Causes of the Deterioration of Soviet Productivity Growth in the Period 1976-80,' in Soviet Economy in the 1980's: Problems and Prospects, Joint Economic Committee, Congress of the United States, US Government Printing Office: Washington, DC, pp. 153168.

May, J., W. Pyle and P. Sommers, 'Does Governance Explain Unofficial Activity,' Applied Economics Letters, forthcoming.

Millar, J., ed. (1987), Politics, Work, and Daily Life in the USSR : A Survey of Former Soviet Citizens, Cambridge University Press: Cambridge, Mass.

Narodnoe khoriaistvo SSSR v 1980 godu, Moscow: Finansy i statistika. 


\section{William Davidson Institute Working Paper 436}

Noren, J. and L. Kurtzweg (1993), 'The Soviet Economy Unravels: 1985-91,' in The Former Soviet Union in Transition, v. 1, Joint Economic Committee, Congress of the United States, US Government Printing Office: Washington, DC, pp. 8-33.

Ofer, G. and A. Vinokur (1992), The Soviet Household Under the Old Regime: Economic Conditions and Behavior in the 1970s, Cambridge University Press: Cambridge, Mass.

Reed, J. (1995), 'The Great Growth Race,' Central European Economic Review, December -January, pp. 8-10.

Rosser, J., M. Rosser and E. Ahmed (2000), 'Income Inequality and the Informal Economy in Transition Economies,' Journal of Comparative Economics, 28, pp. 156-171.

Rutgaizer, V. (1992) 'The Shadow Economy in the USSR,' Berkeley-Duke Occasional Papers on the Second Economy in the USSR, No. 34, February.

Schneider, F. and D. Enste (2000), 'Shadow Economies: Size, Causes, and Consequences,' Journal of Economic Literature, 38, pp. 77-114.

Smith, P. 'Assessing the Size of the Underground Economy: The Statistics Canada Perspective,' in Lippert, O. and M. Walker (eds.), The Underground Economy: Global Evidence of Its Size and Impact, The Fraser Institute: Vancouver, Canada, 1997, pp. 11-36.

Treml, V. (1992), “A Study of Labor Inputs Into the Second Economy of the USSR,” BerkeleyDuke Occasional Papers on the Second Economy in the USSR, No. 33, January. 
William Davidson Institute Working Paper 436

Table 1. Output Elasticity of Electricity-consumption

\begin{tabular}{|l|c|c|c|}
\hline Elasticity & Central and East Europe & Baltic Countries & Former Soviet Union \\
\hline Output Rises & 0.9 & 1.0 & 1.15 \\
\hline Output Falls & 1.11 & 1.0 & 0.87 \\
\hline
\end{tabular}

Note: Output elasticity of electricity-consumption measures the percentage change in measured electricity consumption divided by the percentage change in total GDP. 
William Davidson Institute Working Paper 436

Table 2. Unofficial Economy's Share of Total Output: Kaufmann and Kaliberda's Methodology

\begin{tabular}{|c|c|c|c|}
\hline Central and Eastern Europe & $\mathbf{1 9 8 9}$ & $\mathbf{1 9 9 4}$ & $\mathbf{1 9 9 5}$ \\
\hline Bulgaria & 22.8 & 29.1 & 36.2 \\
\hline Czech Republic & 6.0 & 17.6 & 11.3 \\
\hline Hungary & 27.0 & 27.7 & 29.0 \\
\hline Poland & 15.7 & 15.2 & 12.6 \\
\hline Romania & 22.3 & 17.4 & 19.1 \\
\hline Slovakia & 6.0 & 14.6 & 5.8 \\
\hline Former Soviet Union & & & \\
\hline Azerbaijan & 12.0 & 58.0 & 60.6 \\
\hline Belarus & 12.0 & 18.9 & 19.3 \\
\hline Estonia & 12.0 & 25.1 & 11.8 \\
\hline Georgia & 12.0 & 63.5 & 62.6 \\
\hline Kazakhstan & 12.0 & 34.1 & 34.3 \\
\hline Latvia & 12.0 & 34.2 & 35.3 \\
\hline Lithuania & 12.0 & 28.7 & 21.6 \\
\hline Moldova & 12.0 & 39.7 & 35.7 \\
\hline Russia & 12.0 & 40.3 & 41.6 \\
\hline Ukraine & 12.0 & 45.7 & 48.9 \\
\hline Uzbekistan & 12.0 & 9.5 & 6.5 \\
\hline
\end{tabular}

Note: Neither Kaufmann and Kaliberda (1996) nor Johnson et al. (1997) presented estimates for Armenia, Kyrgyzstan, Tadzhikistan or Turkmenistan. See p. 176 in Johnson et al. (1997).

Source: Johnson et al. (1997). 


\section{William Davidson Institute Working Paper 436}

\section{Table 3. Per Capita Incomes from Official and Unofficial Sources: Berkeley-Duke Survey}

\begin{tabular}{|c|c|c|c|c|c|}
\hline \multicolumn{2}{|c|}{ Region } & $\begin{array}{c}\text { Number of } \\
\text { observations }\end{array}$ & $\begin{array}{c}\text { Socialist } \\
\text { income }\end{array}$ & $\begin{array}{c}\text { Total personal } \\
\text { income }\end{array}$ & $\begin{array}{c}\text { Unofficia } \\
\text { income }\end{array}$ \\
\hline North zone & 1944 & 1280 & 1890 & 610 \\
\hline \multicolumn{2}{|c|}{ Russia-Baltic subzone } & 1384 & 1270 & 1780 & 510 \\
\hline & Russia & 1057 & 1330 & 1830 & 500 \\
\hline & Belorussia-Moldavia-Ukraine & 560 & 1300 & 2170 & 870 \\
\hline \multicolumn{2}{|l|}{ South zone excluding Armenia } & 361 & 1350 & 2190 & 840 \\
\hline
\end{tabular}

Notes: 1. North zone includes Russia, Ukraine, Belorussia, the Baltic republics, and Moldavia. South zone includes all other republics. We exclude Armenia because, like Kaufmann and Kaliberda we do not have the electricity consumption data that would be necessary for our subsequent estimates. 2. We refer to the former Soviet republics by their Soviet names.

Source: Grossman (1991), pp. 13-16. 
William Davidson Institute Working Paper 436

Table 4. Per Capita Incomes from Official and Unofficial Sources for 11 Soviet Republics: Berkeley-Duke Survey

\begin{tabular}{|l|c|c|c|c|c|}
\hline \multicolumn{1}{|c|}{ Region } & $\begin{array}{c}\text { Number of } \\
\text { observations }\end{array}$ & $\begin{array}{c}\text { Socialist } \\
\text { income }\end{array}$ & $\begin{array}{c}\text { Total } \\
\text { personal } \\
\text { income }\end{array}$ & $\begin{array}{c}\text { Unofficial } \\
\text { income }\end{array}$ & $\begin{array}{c}\text { Share of } \\
\text { unofficial } \\
\text { income }\end{array}$ \\
\hline Russia & 1057 & 1330 & 1830 & 500 & 0.27 \\
\hline Baltic republics & 327 & 1076.1 & 1618.4 & 542.3 & 0.34 \\
\hline Belorussia-Moldavia & 199 & 1209.3 & 2133.7 & 924.4 & 0.43 \\
\hline Ukraine & 361 & 1350 & 2190 & 840 & 0.38 \\
\hline $\begin{array}{l}\text { South zone } \\
\text { excluding Armenia }\end{array}$ & 488 & 896 & 1780 & 884 & 0.50 \\
\hline
\end{tabular}

Source: Authors' calculations based on Grossman (1991), pp. 13-16. 


\section{William Davidson Institute Working Paper 436}

Table 5. Estimated Shares of Unofficial Economy in 11 Republics of the FSU, 1989

\begin{tabular}{|l|c|c|c|c|c|}
\hline & $\begin{array}{c}\text { Official } \\
\text { GNP } \\
\text { (mln. rub.) }\end{array}$ & $\begin{array}{c}\text { Unofficial } \\
\text { economy } \\
\text { share, 1979 }\end{array}$ & $\begin{array}{c}\text { Extrapolated } \\
\text { shares of } \\
\text { unofficial } \\
\text { economy, 1989 }\end{array}$ & $\begin{array}{c}\text { Unofficial } \\
\text { GNP } \\
\text { (mln. rub.) }\end{array}$ & $\begin{array}{c}\text { Total } \\
\text { GNP } \\
\text { (mln. rub.) }\end{array}$ \\
\hline Azerbaijan & 14,697 & 0.50 & 0.33 & 7,166 & 21,863 \\
\hline Belarus & 40,100 & 0.43 & 0.29 & 16,058 & 56,158 \\
\hline Estonia & 7,977 & 0.34 & 0.22 & 2,265 & 10,242 \\
\hline Georgia & 14,900 & 0.50 & 0.33 & 7,265 & 22,165 \\
\hline Kazakhstan & 46,363 & 0.50 & 0.33 & 22,606 & 68,969 \\
\hline Latvia & 12,488 & 0.34 & 0.22 & 3,546 & 16,034 \\
\hline Lithuania & 12,897 & 0.34 & 0.22 & 3,662 & 16,559 \\
\hline Moldova & 12,681 & 0.43 & 0.29 & 5,078 & 17,759 \\
\hline Russia & 626,300 & 0.27 & 0.18 & 137,786 & 764,086 \\
\hline Ukraine & 164,761 & 0.38 & 0.25 & 55,847 & 220,608 \\
\hline Uzbekistan & 32,430 & 0.50 & 0.33 & 15,813 & 48,243 \\
\hline Total & 985,594 & 0.34 & 0.22 & 277,094 & $1,262,688$ \\
\hline
\end{tabular}

Sources: Official GNP is from World Bank (1993), Table 2b, pp. 10-11. We used the GNP data for 1990, because this was the earliest year for which such data were available to us. Given that we used these data only as relative weights, the difference between 1990 and 1989 must have been negligible. Unofficial economy shares for 1979 are calculated based on Grossman (1991). 


\section{William Davidson Institute Working Paper 436}

Table 6. Estimates of Unofficial Economies in 1995

\begin{tabular}{|l|c|c|c|c|c|}
\hline & $\begin{array}{c}\text { Unofficial } \\
\text { economy } \\
\text { share, 1989 } \\
(\%)\end{array}$ & $\begin{array}{c}\text { Index of } \\
\text { official } \\
\text { GDP, 1995 } \\
(1989=100)\end{array}$ & $\begin{array}{c}\text { Index of } \\
\text { electricity } \\
\text { output, 1995 } \\
(1989=100)\end{array}$ & $\begin{array}{c}\text { Unofficial } \\
\text { economy } \\
\text { share, 1995 } \\
(\%)\end{array}$ & $\begin{array}{c}\text { Unofficial economy } \\
\text { share, 1995 Johnson } \\
\text { et al. (1997) } \\
(\%)\end{array}$ \\
\hline Azerbaijan & 32.8 & 31.4 & 70.1 & 69.9 & 60.6 \\
\hline Belarus & 28.6 & 56.1 & 61.2 & 34.5 & 19.3 \\
\hline Estonia & 22.1 & 69.1 & 68.9 & 21.9 & 11.8 \\
\hline Georgia & 32.8 & 16.0 & 37.6 & 71.4 & 62.6 \\
\hline Kazakhstan & 32.8 & 46.5 & 62.3 & 49.8 & 34.3 \\
\hline Latvia & 22.1 & 47.3 & 62.3 & 40.9 & 35.3 \\
\hline Lithuania & 22.1 & 45.1 & 50.6 & 30.6 & 21.6 \\
\hline Moldova & 28.6 & 43.0 & 58.8 & 47.8 & 35.7 \\
\hline Russia & 18.0 & 49.1 & 74.0 & 45.6 & 41.6 \\
\hline Ukraine & 25.3 & 39.0 & 67.0 & 56.5 & 48.9 \\
\hline Uzbekistan & 32.8 & 84.0 & 79.0 & 28.5 & 6.5 \\
\hline
\end{tabular}

Sources: Columns 1 and 4 are based on authors' calculations. Columns 2, 3 and 5 are from

Table 1 in Johnson et al. (1997). 


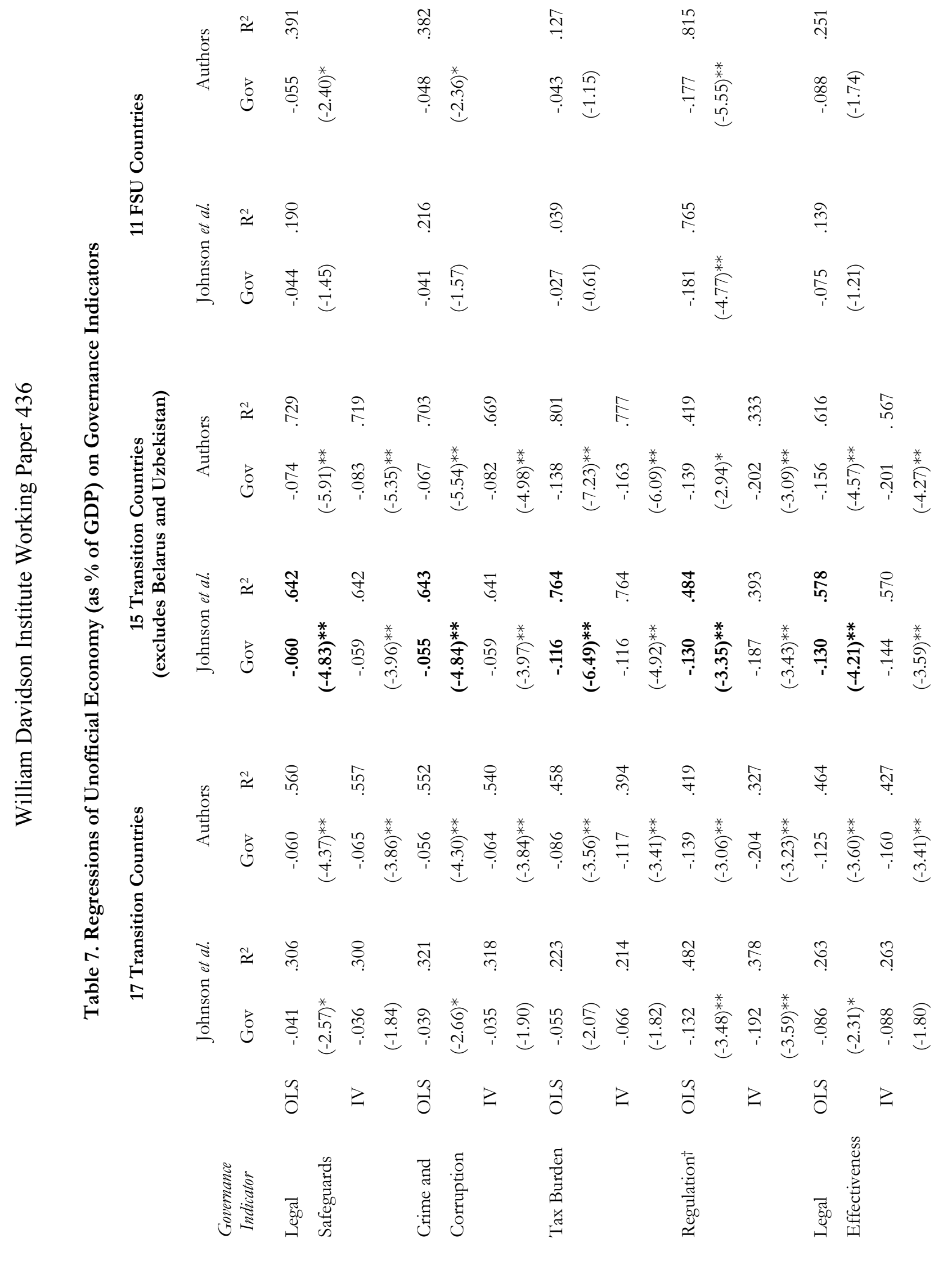




\section{William Davidson Institute Working Paper 436}

Numbers in parentheses are $t$-statistics; numbers under "Gov" are coefficients on governance variables.

*Significant at $5 \%$ level; **Significant at $1 \%$ level.

Boldened results are those reported in Johnson et al. (1997).

†For "regulation," no observations for Kazakhstan and Uzbekistan.

Sources: The legal safeguards, crime and corruption and tax burden variables were taken from the December 1995-January 1996 issue of the. A panel of eight experts was asked to rank 26 transition countries on the basis of a number of factors affecting business. Grades were given on a scale of 0 to 10 , with 10 representing the best environment for business. The panel members included: Dirk Damrau, Salomon Brothers Internation; Susanne Gahler, JP Morgan; Donald Green, PlanEcon; Andreas Gummich, Deutsche Bank Research; Peter Havlik, Vienna Institute for Comparative Economic Studies; Jonathan Hoffman, CS First Boston; James Lister-Cheese, Independent Strategy; and Werner Varga, Creditanstalt Bankverein. In their article, Johnson et al. (1997) refer to the "tax fairness" and "corruption" variables from the survey in the Central European Economic Review; the survey actually asked about "tax burden" and "crime and corruption."

The regulation variable was created by experts at the Heritage Foundation (see www.heritage.org/index). The original scale was from 0 to 4 , with 0 meaning that there is little or no corruption, existing regulations are straightforward, not burdensome and applied uniformly to all businesses. We follow Johnson et al. (1997) by reversing the scale so that 4 means the least burdensome regulation, allowing us to consistently have the probusiness governance scored with the higher numbers.

As reported in Johnson et al. (1997), we use the European Bank for Reconstruction and Development's "legal effectiveness" index for 1995. 


\section{William Davidson Institute Working Paper 436}

Table 8. Regressions of Unofficial Economy (as \% of GDP) on Governance Indicators and Estimated Share of Unofficial Economy in 1989

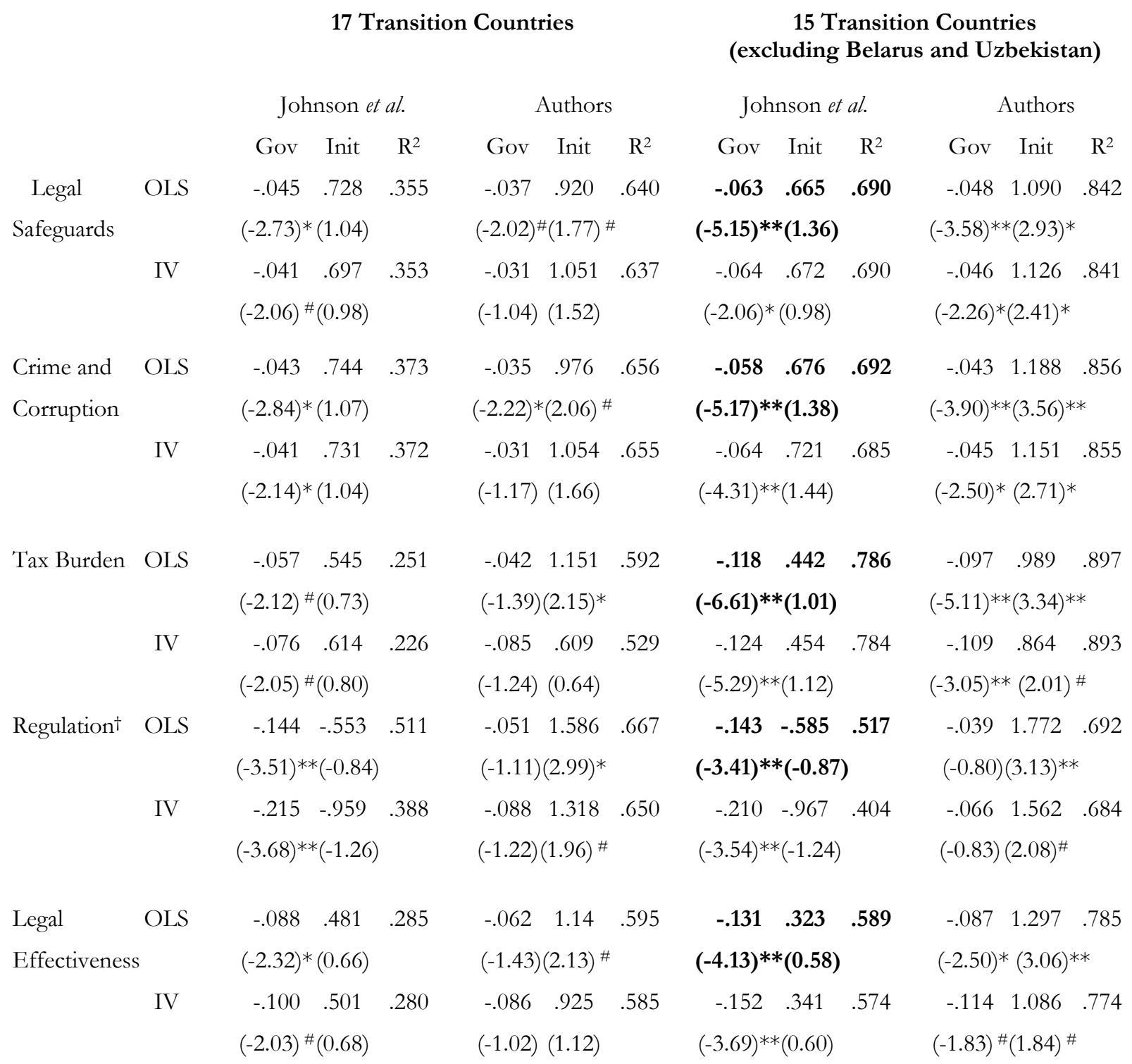

Numbers in parentheses are $t$-statistics; numbers under "Gov" are coefficients on governance variables; "Init" is the share of the unofficial economy in 1989 as estimated by Johnson et al. and the authors, respectively.

\# Significant at 10\% level; * Significant at 5\% level; ** Significant at 1\% level.

Boldened results are those reported in Johnson et al. (1997).

tFor "regulation," no observations for Kazakhstan and Uzbekistan.

Sources: See note in Table 7. All governance data are for 1995. 


\section{Appendix}

\section{Table 1A. Regressions of Unofficial Economy (as \% of GDP) on Governance Indicators and Soviet Dummy}

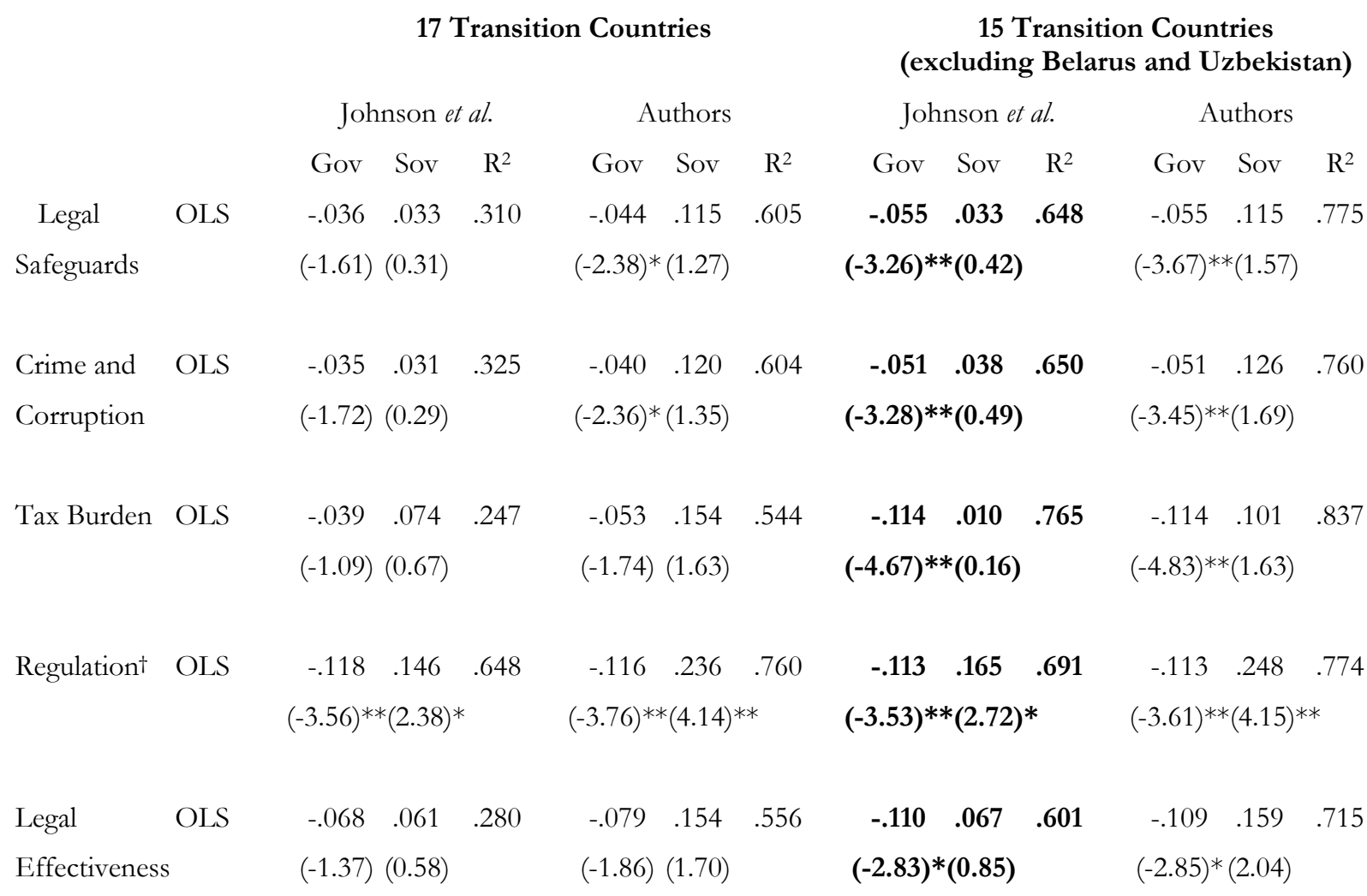

Numbers in parentheses are $t$-statistics; numbers under "Gov" are coefficients on governance variables; "Sov" is a dummy variable for former Soviet republics.

* Significant at 5\% level; ** Significant at 1\% level.

Boldened results are those reported in Johnson et al. (1997).

†For "regulation," no observations for Kazakhstan and Uzbekistan.

Sources: see note in Table 7. All governance data are for 1995. 


\section{William Davidson Institute Working Paper 436}

Table 2A. Regressions of Unofficial Economy (as \% of GDP) on Governance Indicators

\begin{tabular}{lcccc} 
& \multicolumn{2}{c}{ Lacko } & \multicolumn{2}{c}{ Authors } \\
& Gov & $\mathrm{R}^{2}$ & Gov & $\mathrm{R}^{2}$ \\
Legal & -.015 & .428 & -.060 & .552 \\
Safeguards & $(-3.24)^{* *}$ & $(-4.16)^{* *}$ \\
Crime and & -.013 & .407 & -.055 & .543 \\
Corruption & $(-3.10)^{* *}$ & $(-4.08)^{* *}$ \\
Tax Burden & -.023 .415 & -.086 & .470 \\
& $(-3.15)^{* *}$ & $(-3.52)^{* *}$ \\
Regulationt & -.032 & .282 & $-.141 \quad .446$ \\
& $(-2.17)^{*}$ & $(-3.11)^{* *}$ \\
Legal & -.031 & .354 & -.124 .470 \\
Effectiveness & $(-2.85)^{*}$ & $(-3.52)^{* *}$
\end{tabular}

Note: Lacko produced estimates for the ratio of the hidden economy to the official GDP. Since we and Johnson et al. (1997) used the ratio of the hidden economy to total GDP as our dependent variable, we adjust Lacko's estimates according to the following formula: $\mathrm{L} /(1+\mathrm{L})$, where $\mathrm{L}$ refers to Lacko's estimate of the ratio of the hidden economy to official GDP. We thus convert her estimates into the ratio of the hidden economy to total GDP. She produces estimates for twenty countries. The above regressions are, however, just run for the sixteen countries for which we both have estimates. These are the seventeen countries listed in Table 2 minus Moldova. 
William Davidson Institute Working Paper 436

Table 3A. Regressions of Unofficial Economy (as \% of GDP) on World Bank Governance Indicators

\begin{tabular}{|c|c|c|c|c|c|}
\hline \multirow{3}{*}{$\begin{array}{l}\text { Governance } \\
\text { Indicator }\end{array}$} & \multicolumn{3}{|c|}{17 Transition Economies } & \multicolumn{2}{|c|}{15 Transition Economies } \\
\hline & \multicolumn{2}{|c|}{ Johnson et al. } & Authors & Johnson et al. & Authors \\
\hline & Gov & $\mathrm{R}^{2}$ & Gov & Gov & Gov \\
\hline $\begin{array}{l}\text { Voice and } \\
\text { Accountability }\end{array}$ & $\begin{array}{c}-.084 \\
(-1.54)\end{array}$ & .136 & $\begin{array}{l}-.151 \quad .370 \\
(-2.97)^{* *}\end{array}$ & $\begin{array}{c}-.200 \quad .588 \\
(-4.31)^{* *}\end{array}$ & $\begin{array}{l}-.251 .680 \\
(-5.26)^{* *}\end{array}$ \\
\hline $\begin{array}{l}\text { Political } \\
\text { Instability }\end{array}$ & $\begin{array}{c}-.167 \\
(-2.59)^{*}\end{array}$ & .309 & $\begin{array}{c}-.226 .477 \\
(-3.70)^{* *}\end{array}$ & $\underset{(-4.22)^{* *}}{-.225} .578$ & $\begin{array}{c}-.265 .588 \\
(-4.31)^{* *}\end{array}$ \\
\hline $\begin{array}{l}\text { Government } \\
\text { Effectiveness }\end{array}$ & $\begin{array}{l}-.115 \\
(-1.64)\end{array}$ & .153 & $\begin{array}{c}-.180 \\
(-2.64) *\end{array}$ & $\underset{(-3.33)^{* *}}{-.209} .460$ & $\begin{array}{c}-.249 \\
(-3.47)^{* *}\end{array} .481$ \\
\hline $\begin{array}{l}\text { Regulatory } \\
\text { Burden }\end{array}$ & $\begin{array}{c}-.077 \\
(-1.32)\end{array}$ & .105 & $\begin{array}{c}-.143 \\
(-2.58) *\end{array}$ & $\begin{array}{c}-.228 \\
(-4.45)^{* *}\end{array}$ & $\begin{array}{c}-.278 .664 \\
(-5.07)^{* *}\end{array}$ \\
\hline $\begin{array}{l}\text { Rule } \\
\text { of Law }\end{array}$ & $\begin{array}{l}-.139 \\
(-1.79)\end{array}$ & .176 & $\begin{array}{c}-.217 \\
(-2.92) *\end{array}$ & $\begin{array}{c}-.270 .561 \\
(-4.07)^{* *}\end{array}$ & $\begin{array}{c}-.319 .579 \\
(-4.23) * *\end{array}$ \\
\hline Graft & $\begin{array}{c}-.175 \\
(-2.59)^{*}\end{array}$ & .309 & $\begin{array}{c}-.239 \\
(3.78)^{* *}\end{array}$ & $\underset{(-4.51)^{* *}}{-.244} .611$ & $\begin{array}{c}-.286 .618 \\
(-4.59) * *\end{array}$ \\
\hline
\end{tabular}

Numbers in parentheses are $t$-statistics; numbers under "Gov" are coefficients on governance variables.

*Significant at 5\% level; **Significant at 1\% level.

Note: May et al. (forthcoming) first noted the relatively poor fit between these governance variables and the unofficial economy estimates of Johnson et al. (1997).

Source: World Bank. 


\section{William Davidson Institute Working Paper 436}

\section{ENDNOTES}

${ }^{1}$ Our use of Berkeley-Duke data is justified in part because it was the only family budget survey specifically aimed at studying the unofficial or second economy in the USSR and because Kaufmann and Kaliberda claim to have derived their estimates, in part, from Berkeley-Duke data.

${ }^{2}$ Dobozi and Pohl (1995) first addressed the degree of correlation between measured output and electricity consumption during the transition.

${ }^{3}$ Kaufmann and Kaliberda note several biases in using electricity consumption as a proxy for overall GDP. Applying a near-unit-elasticity assumption could lead to incorrectly high estimates of total output if the economy slumps and electricity is primarily a fixed cost, or if electricity costs rise because of a lack of basic maintenance, or if energy users substitute from other sources to electricity. Downward biases could result from improved efficiency in electricity use, price-induced substitution away from electricity, or a shift in output away from electricity-intensive industries. On balance, they feel that the upward and downward biases offset each other.

${ }^{4}$ This figure is calculated with the assumption of unitary output elasticity of electricity consumption and according to the formula (105-92.7)/105=11.7\%.

${ }^{5}$ See footnote 25 in Kaufmann and Kaliberda (1996).

${ }^{6}$ Kaufmann and Kaliberda produce estimates for 1994 and present them in a bar graph that indicates the relative sizes of unofficial economies across republics. Exact percentages are not provided. Johnson et al. (1997) use the same methodology and baseline estimates to update the estimates for 1995. They provide the exact percentages for both 1994 and 1995.

7 Rutgaizer (1992) presents a survey of estimates made by Soviet researchers who, as he stresses, provided virtually no substantiation for their numbers. The estimates from other surveys of emigrants out of the USSR are reported in Ofer and Vinokur (1992) and Millar (1987). Note, however, that unlike the Berkely-Duke project, neither of these surveys focused on the study of the underground economy.

${ }^{8}$ See Smith (1997) for arguments along these lines.

${ }^{9}$ See footnote 23 in Kaufmann and Kaliberda. Braithwaite's estimate of approximately 13\% of the labor force being engaged in the unofficial economy relates to the post-1992 period. More important, her estimate is derived under the apparent assumption that none of the full-time officially employed individuals participated in the unofficial economy. We think that this assumption is at great odds with casual observation and undermines the validity of Braithwaite's estimates.

${ }_{10}$ Note, however, that a significant share of unofficial income was obtained by using state-owned capital at state-owned enterprises.

11 The estimates of the dynamics of unofficial economy made by the Soviet researchers are summarized in Rutgaizer (1992). Alexeev and Treml (1994) provide some econometric evidence of its growth. See also Alexeev (1997) for a discussion of the reasons for the growth of the underground economy in the USSR in the late 1980 's.

12 The CIA estimates of Soviet GNP growth for 1980 are reported in Levine (1983). Noren and Kurtzweg (1993) present CIA GNP growth estimates for 1981-1989 and electricity output growth rates for the same period. The growth rate of electricity output for 1980 was calculated based on Narodnoe (1981).

13 This number is obtained as $(1.36-0.88 \cdot 1.21) / 1.36 \approx 0.22$. We use unitary elasticity of output with respect to electricity consumption for the 1979-89 period essentially by default, as we do not have strong priors for the value of this elasticity in the former USSR. 


\section{William Davidson Institute Working Paper 436}

14 To derive this formula, normalize the total 1989 GDP to 1 . Then the official 1995 GDP can be obtained as $\mathrm{X}_{\mathrm{OF}} \cdot\left(1-\mathrm{UE}_{89}\right)$, implying that the unofficial economy in 1995 is $\mathrm{X}_{\mathrm{EL}}-\mathrm{X}_{\mathrm{OF}} \cdot\left(1-\mathrm{UE}_{89}\right)$. The formula for the share of this unofficial economy is then obtained by dividing the latter expression by $\mathrm{X}_{\mathrm{EL}}$.

15 Tables 2 and 3 in Johnson et al. (1997) also present regressions with several other governance variables which we have chosen not to present here. The data for "internal liberalization" were not available publicly. "External liberalization" and "large-scale privatization" do not relate as directly to governance and firm-level decisions to enter the underground economy as variables measuring the legal, regulatory and tax environments. "Rule of law" was constructed in 1997, two years subsequent to the unofficial economy data; the origins of the "legal extensiveness" data were not clear.

16 In later studies using cross-section data that included OECD and developing countries, Johnson et al. (1998) and Friedman et al. (2000) continued to use the same set of unofficial economy size estimates for transition countries. These had been constructed with output and electricity consumption data through 1995. These later studies, however, regressed these estimates on a number of governance indicators that had been created after 1995.

${ }^{17}$ In Johnson et al. (1998) and Friedman et al. (2000), the argument about the uniqueness of these countries is not made and Belarus and Uzbekistan are included in the regressions.

18 Using growth rate of the shares during 1989-95 period would have presented its own problems, because higher initial shares would tend to grow slowly simply because they would have less room for growth. In the limit, if a country's share of unofficial economy is $100 \%$, it could only decline. 


\section{DAVIDSON INSTITUTE WORKING PAPER SERIES - Most Recent Papers}

The entire Working Paper Series may be downloaded free of charge at: www.wdi.bus.umich.edu

CURRENT AS OF 3/12/02

\begin{tabular}{|c|c|c|}
\hline Publication & Authors & Date \\
\hline $\begin{array}{l}\text { No. 436: A Note on Measuring the Unofficial Economy in the Former } \\
\text { Soviet Republics }\end{array}$ & $\begin{array}{l}\text { Michael Alexeev and William } \\
\text { Pyle }\end{array}$ & Sept. 2001 \\
\hline $\begin{array}{l}\text { No. 435: The Ownership School vs. the Management School of State } \\
\text { Enterprise Reform: Evidence from China }\end{array}$ & David D. Li and Changqi Wu & Jan. 2002 \\
\hline $\begin{array}{l}\text { No. } 434 \text { Forthcoming in: The Journal of Economic Perspectives, "The } \\
\text { Effect of Ownership and Competitive Pressure on Firm Performance in } \\
\text { Transition Countries: Micro Evidence from Bulgaria, Romania and } \\
\text { Poland," 16(2) Feb. } 2002 .\end{array}$ & $\begin{array}{l}\text { Manuela Angelucci, Saul Estrin, } \\
\text { Jozef Konings, Zbigniew } \\
\text { Zolkiewski }\end{array}$ & Jan. 2002 \\
\hline No. 433: The End of Moderate Inflation in Three Transition Economies? & Josef C. Brada and Ali M. Kutan & Jan. 2002 \\
\hline $\begin{array}{l}\text { No. 432: What Drives the Speed of Job Reallocation During Episodes of } \\
\text { Massive Adjustment? }\end{array}$ & $\begin{array}{l}\text { Stepan Jurajda and Katherine } \\
\text { Terrell }\end{array}$ & Jan. 2002 \\
\hline No. 431: Competition and Corporate Governance in Transition & Saul Estrin & Dec. 2001 \\
\hline $\begin{array}{l}\text { No. 430: Corporate Governance in the Cause of Peace: An } \\
\text { Environmental Perspective }\end{array}$ & Don Mayer & Jan. 2002 \\
\hline No. 429: Why do Governments Privatize? & $\begin{array}{l}\text { Loren Brandt, Hongbin Li, and } \\
\text { Joanne Roberts }\end{array}$ & Dec. 2001 \\
\hline No. 428: Testing Russia's Virtual Economy & Vlad Ivanenko & Dec. 2001 \\
\hline No. 427: War and the Business Corporation & Eric W. Orts & Dec. 2001 \\
\hline $\begin{array}{l}\text { No. 426: Partial Privatization and Firm Performance: Evidence from } \\
\text { India }\end{array}$ & Nandini Gupta & Dec. 2001 \\
\hline $\begin{array}{l}\text { No. 425: Direct Foreign Investments and Productivity Growth in } \\
\text { Hungarian Firms, 1992-1999 }\end{array}$ & Jérôme Sgard & Nov. 2001 \\
\hline $\begin{array}{l}\text { No. 424: Banking Passivity and Regulatory Failure in Emerging } \\
\text { Markets: Theory and Evidence from the Czech republic. }\end{array}$ & Jan Hanousek and Gerard Roland & July 2001 \\
\hline $\begin{array}{l}\text { No. 423: Conceptions of the Corporation and the Prospects of } \\
\text { Sustainable Peace }\end{array}$ & Jeffrey Nesteruk & Dec. 2001 \\
\hline No. 422: The Role of the Corporation in Fostering Sustainable Peace & Timothy Fort and Cindy Schipani & Nov. 2001 \\
\hline No. 421: Wage Arrears and the Distribution of Earnings in Russia & $\begin{array}{l}\text { Hartmut Lehmann and Jonathan } \\
\text { Wadsworth }\end{array}$ & Dec. 2001 \\
\hline $\begin{array}{l}\text { No. 420: Transferring Collective Knowledge: Collective and } \\
\text { Fragmented Teaching and Learning in the Chinese Auto Industry }\end{array}$ & $\begin{array}{l}\text { Jane Zhou, Jaideep Anand, and } \\
\text { Will Mitchell }\end{array}$ & Dec. 2001 \\
\hline $\begin{array}{l}\text { No. 419: Liberalization, Corporate Governance, and the Performance of } \\
\text { Newly Privatized Firms }\end{array}$ & $\begin{array}{l}\text { Narjess Boubakri, Jean-Claude } \\
\text { Cosset, and Omrane Guedhami }\end{array}$ & Dec. 2001 \\
\hline $\begin{array}{l}\text { No. 418: The European Data Privacy Directive and International } \\
\text { Relations }\end{array}$ & Steven R. Salbu & Dec. 2001 \\
\hline $\begin{array}{l}\text { No. 417: Capital Markets and Capital Allocation: Implications for } \\
\text { Economies in Transition }\end{array}$ & $\begin{array}{l}\text { Artyom Durnev, Randall Morck, } \\
\text { and Bernard Yeung }\end{array}$ & Dec. 2001 \\
\hline $\begin{array}{l}\text { No. 416: Forthcoming in: The Journal of Economic Perspectives, "Data } \\
\text { Watch. Research Data from Transition Economies," 16(2) Feb. } 2002 .\end{array}$ & $\begin{array}{l}\text { Randall K. Filer and Jan } \\
\text { Hanousek }\end{array}$ & Dec. 2001 \\
\hline $\begin{array}{l}\text { No. 415: Forthcoming in: The Journal of Economic Perspectives, } \\
\text { "Transition Economies: Performance and Challenges," 16(2) Feb. } 2002 .\end{array}$ & Jan Svejnar & Dec. 2001 \\
\hline $\begin{array}{l}\text { No. } 415 \text { Forthcoming in: The Journal of Economic Perspectives, } \\
\text { "Transition Economies: Performance and Challenges," 16(2) Feb. } 2002 .\end{array}$ & Jan Svejnar & Dec. 2001 \\
\hline $\begin{array}{l}\text { No. } 414 \text { Forthcoming in: The Journal of Economic Perspectives, "The } \\
\text { Great Divide and Beyond: Financial Architecture in Transition," 16(2) } \\
\text { Feb. 2002. }\end{array}$ & Erik Berglof and Patrick Bolton & Dec. 2001 \\
\hline $\begin{array}{l}\text { No. } 413 \text { Forthcoming in: The Journal of Economic Perspectives, "The } \\
\text { Political Economy of Transition," 16(2) Feb. } 2002 .\end{array}$ & Gérard Roland & Dec. 2001 \\
\hline $\begin{array}{l}\text { No. 412: The Response of Consumption in Russian Households to } \\
\text { Economic Shocks }\end{array}$ & Steven Stillman & Oct. 2001 \\
\hline
\end{tabular}


